\title{
The collapse and recovery potential of carbon sequestration by baleen whales in the Southern Ocean
}

\section{Anaelle Durfort}

University of Montpellier

\section{Gael Mariani}

University of Montpellier https://orcid.org/0000-0003-3816-5583

\section{Marc Troussellier}

University of Montpellier

\section{Vivitskaia Tulloch}

University of British Columbia

David Mouillot ( $\nabla$ david.mouillot@umontpellier.fr)

University of Montpellier https://orcid.org/0000-0003-0402-2605

\section{Article}

Keywords: Natural Climate Solutions, climate change, population dynamics, modelling, krill

Posted Date: October 23rd, 2020

DOl: https://doi.org/10.21203/rs.3.rs-92037/v1

License: (c) (1) This work is licensed under a Creative Commons Attribution 4.0 International License. Read Full License 
1

2

3

4

5

6

7

8

9

10

11

12

13

14

15

16

17

18

19

20

21

22

23

24

25

26

27

28

29

30

31 24 25 6 27
The collapse and recovery potential of carbon sequestration by baleen whales in the Southern Ocean

Anaelle Durfort ${ }^{1}$, Gael Mariani ${ }^{1}$, Vivitskaia Tulloch ${ }^{2}$, Marc Troussellier $^{1}$ \& David Mouillot ${ }^{1,3^{*}}$

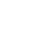

${ }^{1}$ MARBEC, University of Montpellier, CNRS, IFREMER, IRD, Montpellier, France

${ }^{2}$ Department of Forest and Conservation Science, University of British Columbia, Vancouver, Canada

${ }^{3}$ Institut Universitaire de France, IUF, Paris 75231, France

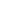

3

5 Corresponding author:

D. Mouillot

7 MARine Biodiversity, Exploitation and Conservation UMR 9190 MARBEC

8 Cc093, Bat. 24. Université de Montpellier

9 Rue du Truel

34095 Montpellier Cedex 5

1 France

22 Phone: +33 (0)4 67144297

3 E-mail: david.mouillot@umontpellier.fr 

4

\section{Abstract}

Limiting climate warming below $2^{\circ} \mathrm{C}$ requires both reducing anthropic greenhouse gas emissions and sequestering more atmospheric carbon. Natural Climate Solutions (NCS) rely on the ability of ecosystems to capture and store carbon. Despite the important role of marine megafauna on the ocean carbon cycle, its potential as a NCS has not yet been explored. Here, we quantify the amount of carbon potentially sequestered by five baleen whale species across the Southern Hemisphere between 1890 and 2100 through both the sinking of carcasses after natural death and the fertilisation of phytoplankton by nutrients in faeces. At their pre-exploitation abundances, the five whales could sequester $10.610^{6}$ tonnes of carbon per year (tC.yr-1) but this natural carbon sink was reduced at $210^{6}$ tC. $\mathrm{yr}^{-1}$ in 1965 due to commercial whaling. However, the restoration of whale populations could sequester $8.710^{6} \mathrm{tC} . \mathrm{yr}^{-1}$ at the end of the $21^{\text {st }}$ century suggesting an efficient but neglected NCS that remains to be estimated globally including all marine vertebrates.

Keywords: Natural Climate Solutions, climate change, population dynamics, modelling, krill (1)

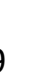

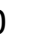

(1)


The concentration of atmospheric carbon dioxide $\left(\mathrm{CO}_{2}\right)$ has dramatically increased since the beginning of the industrial era, from about 277 parts per million (ppm) in 1750 to over $410 \mathrm{ppm}$ today ${ }^{1}$. The rise of this greenhouse gas (GHG) in the atmosphere is changing the climate with a range of damaging consequences for ecosystems and human societies ${ }^{2,3}$. Thus, at the Paris Agreements in 2015, the international community set the objective of containing the global warming below $+2 \mathrm{C}^{\circ}$ compared to pre-industrial levels ${ }^{4}$. The signatory states made the commitment not only to reduce their GHG emissions, but also to implement negative emission actions to remove $\mathrm{CO}_{2}$ from the atmosphere. These actions can be based on emerging technologies like geoengineering ${ }^{5,6}$ but can also rely on the natural capacity of ecosystems to sequester and store carbon ${ }^{7,8}$. These Natural Climate Solutions (NCSs) represent the set of actions for the protection, restoration or sustainable management of ecosystems with the aim of increasing long-term carbon sequestration and limiting the emissions of GHG.

Surprisingly, the open ocean is not subject to any NCS though it absorbs about $22 \%$ of anthropogenic $\mathrm{CO}_{2}$ emissions ${ }^{1}$ and maintains a primary productivity equivalent to that of terrestrial ecosystems ${ }^{9}$. No NCS is based on marine megafauna either although some of these species are the biggest in the animal kingdom, thus accumulating a large amount of carbon over several decades. Marine mammals, especially whales, could therefore have a disproportionate influence on the functioning of ecosystems but also on the global carbon cycle. Here, we focus on baleen whales since they have been identified as ecosystem engineers having an important role in biogeochemical cycling and carbon sequestration ${ }^{10}$ ${ }^{11}$. However, the carbon pump mediated by whales remains poorly understood and quantified. Indeed, carbon sequestration has only been assessed at a given time ${ }^{12}$ or for a limited number of species ${ }^{13}$. One step further, some studies highlighted the importance of megafauna, especially whales, for carbon sequestration through the impact of whaling $^{14}$ but we still lack a long-term dynamic of this sequestration potential under scenarios mixing climate change and whaling.

Whaling has indeed reduced the size of populations by an average of $70 \%{ }^{15}$ and by up to $99.5 \%$ for some species such as the blue and southern right whale ${ }^{16}$. Since 1986, an international moratorium of the International Whaling Commission (IWC) allows populations to recover, but other pressures threaten their recovery, including climate change ${ }^{17-19}$. Therefore, it is essential to evaluate the whale potential for carbon sequestration under different future climatic scenarios. Here we provide the first quantification of both historical and forecasted whale-mediated carbon sequestration trajectories in the southern hemisphere. For this purpose, we used whale abundances modelled from harvesting and survey data from 1890 to the present day and abundances predicted up to 2100 under two climatic 
scenarios ${ }^{16,17}$, one excluding effects of climate change and the other including effects of climate change predicted under the most pessimistic but also the most realistic RCP8.5 scenario ${ }^{20}$.

Whales can sequester carbon via different mechanisms. Here, we considered two sequestration pathways. First, these massive animals can sequester the carbon contained in their biomass via the sinking of their carcasses into the deep ocean after natural death ${ }^{14}$ (Fig. 1a). Secondly, whales can contribute to carbon sequestration indirectly via the fertilisation of surface waters. Indeed, the development of phytoplankton can be limited by the low concentration of nutrients such as nitrogen, phosphorus or iron ${ }^{21}$. Nutrients egested by whales, via their faeces, can thus stimulate phytoplankton productivity and increase carbon sequestration via dead phytoplankton cells that sink into the deep ocean ${ }^{22}$ (Fig. 1b). On top of that, southern whales feed mostly on krill which is an iron accumulator ${ }^{23,24}$ so they can recycle this limiting nutrient in the Southern Ocean. Although the recycling of iron and the subsequent fertilization process mediated by whales were already evaluated ${ }^{13,25}$, the two sequestration pathways (carcasses and fertilization) have never been estimated simultaneously for a community of baleen whales during a long-time period.

In this study, we focused on Southern Hemisphere populations of five species that have been heavily exploited during the first half of $20^{\text {th }}$ century: the blue whale (Balaenoptera musculus), the fin whale (Balaenoptera physalus), humpback whale (Megaptera novaeangliae), the southern right whale (Eubalaena australis) and the Antarctic antarctic minke whale (Balaenoptera bonaerensis), for which comprehensive ecosystem models predicting future abundances were developed ${ }^{16,17}$. These species are very diverse in terms of body size (from 6 tonnes for the antarctic minke whale to 120 tonnes for the blue whale) and IUCN Red List of Threatened Species status (from Endangered to "Minor Concern") (Supplementary Fig. 1). This model is mainly localized in the Southern Ocean (between $40^{\circ}$ and $80^{\circ} \mathrm{S}$ ) during summer when these whales prey on krill; and in the tropics (between 0 and $40^{\circ} \mathrm{S}$ ) during winter when they migrate for the breeding season ${ }^{26}$.

The population dynamics of these five species were estimated from 1890 to 2100 for the Southern Hemisphere using a MICE (Model of Intermediate Complexity for Ecosystem Assessments) model ${ }^{16,17}$. Whale abundances were explained by both the dynamics of their prey (Antarctic krill Euphausia superba and copepods) and the catches (whaling) that were progressively banned between 1960 and 1980. The MICE model was coupled with a NPZD (Nutrient-Phytoplankton-Zooplankton-Detritus) model that considers the influence of climatic conditions on primary productivity to hindcast historical carrying capacity and predict future population trajectories. To take into account the effects of climate change, two versions of the MICE model were used. In the first version, whale dynamics were not coupled to changing climate conditions which were assumed to remain constant from 1890 to 2100 . 
125

126

127

128

129

130

131

132

133

134

135

136

137

138

139

140

141

142

143

144

145

146

147

148

149

150

151

152

153

154

155

156

In the second model, the effects of climate change according to the RCP 8.5 "business as usual" scenario impacted krill and copepod prey availability for whales through the NPZD outputs ${ }^{16,17}$. The outputs of this MICE model were used as inputs for our new carbon sequestration assessments. To calculate the carbon sequestrated via carcasses, we estimated the carbon concentration of carcasses and the biomass of carcasses reaching the deep ocean (see method). For the fertilization sequestration pathway, we estimated the amount of iron supplied to the euphotic zone by whales, and the supplementary amount of carbon sequestrated by phytoplankton owing to this additional nutrient supply (see methods). By coupling these two processes to the whale abundance trajectories we estimated the trend of the whale-mediated carbon pump from 1890 to 2100 including uncertainties.

We show that, by the end of the century, southern whales could sequester between $5.210^{6} \mathrm{tC} . \mathrm{yr}^{-1}$ and $8.910^{6} \mathrm{tC} . \mathrm{yr}^{-1}$, depending on the climate change trajectory. It represents between $50 \%$ and $84 \%$ of the pre-exploitation level after a drop at $210^{6} \mathrm{tC} . \mathrm{yr}^{-1}$ in 1965 due to whaling. We also show that whalemediated carbon sequestration is predominantly due to the fertilization pathway. Our study suggests that this often-neglected carbon sequestration performed by all marine mammals ${ }^{27}$ but also seabirds ${ }^{27-29}$ and fish ${ }^{30-32}$ could be considered as a NCS where populations are restored.

\section{Results}

\section{Carbon sequestration prior to commercial whaling}

We first present estimates of the amount of carbon sequestered by the five baleen whale species across the Southern Hemisphere when they were at their biotic capacity, i.e. at their pre-exploitation levels. Using whale parameters and outputs from the MICE model ${ }^{16,17}$ (see Methods), the annual amount of sequestered carbon was estimated by considering the natural mortality of whale populations as well as the biomass and carbon content of the carcasses (Supplementary Fig. 1). The total pre-exploitation number of mature individuals is about 1.2 million for the five species across the Southern Hemisphere ${ }^{16}$. Dead whales represent each year a biomass of almost 4 million tonnes in this region. The sinking of their carcasses generates a flux of $2.510^{5} \pm 0.510^{5}$ tonnes of carbon per year (tC.yr-1) towards the deep ocean (Fig. 2a). However, not all species contribute equally to this total carbon flux. Fin and blue whales contribute at $48 \%$ and $34 \%$ respectively (Fig. 2a). The other three species have a marginal contribution, particularly southern right whales, which account for only $0.7 \%$ of the total carbon flux.

Living individuals also promote carbon sequestration by stimulating phytoplankton growth via fertilization by egestion. The Southern Ocean is a 'High Nutrient Low chlorophyll' zone because 
concentrations of macronutrients (nitrates and phosphates) are high but primary productivity is low 21. Primary productivity, through phytoplankton growth, is thus limited by the availability of trace elements ( $\mathrm{Fe}, \mathrm{Cu}, \mathrm{Zn}, \mathrm{Co}, \mathrm{Cd})$, especially iron ${ }^{21}$. Iron-rich whale faeces thus stimulate phytoplankton growth and, by extension, carbon sinking ${ }^{33}$. To quantify this sequestration pathway, we estimated the amount of iron supplied in the euphotic zone by whales based on the egestion rate and the bioavailable iron concentration in faeces. At their biotic capacity, the five species defecate about $9.310^{3}$ tonnes (range: $3.210^{3}-18.410^{3}$ tonnes) of iron. About $1110^{2}$ tonnes of this iron (12.2\%) can be used by phytoplankton (see Methods). The phytoplankton carbon flux at 200 metres depth is then $10.410^{6}$ tC.yr-1 (range: $3.610^{6}-20.510^{6} \mathrm{tC} . \mathrm{yr}^{-1}$ ). This is about 40 times more than sequestration via carcasses (Fig. 2b). The main contributing species are fin whales (47\%), followed by blue and southern right whales with $24 \%$ and $16 \%$ respectively. Finally, antarctic minke and humpback whales contribute at only $8 \%$ and $5 \%$, respectively (Fig. 2 b).

Overall the five whales at their pre-exploitation abundances across the Southern Hemisphere can sequester up to $10.610^{6} \mathrm{tC} . \mathrm{yr}^{-1}$ (range: $3.810^{6}-20.810^{6} \mathrm{tC} . \mathrm{yr}^{-1}$ ). The indirect sequestration pathway, via the stimulation of phytoplankton growth, represents about $98 \%$ of the total carbon flux towards the deep sea.

\section{Carbon sequestration dynamics from 1890 to 2100}

We predicted carbon sequestration dynamics from 1890 to 2100 under various exploitation levels and climate change scenarios. A stable phase from 1890 to 1912 was followed by a sharp drop in the amount of carbon sequestered over the exploitation period (Fig. 3). Indeed, all species experienced population declines, particularly the main contributors (fin and blue whales), which were reduced to approximately $3 \%$ and $0.5 \%$ of their pre-exploitation stock, respectively (Supplementary Fig. 2). As a result, carbon sequestration from these Southern Hemisphere whales decreased to a minimum of 2 $10^{6} \mathrm{tC} . \mathrm{yr}^{-1}$ (range: $0.910^{6}$ and $3.710^{6} \mathrm{tC} . \mathrm{yr}^{-1}$ ) in 1965, i.e. $19 \%$ of the pre-exploitation level. In the model without climate change, carbon sequestration would reach $8.910^{6}$ tC.yr-1 (range: $3.410^{6}$ and $1710^{6}$ $\mathrm{tC} . \mathrm{yr}^{-1}$ ) in 2100 under the predicted increase of antarctic minke whale populations and the recovery of all other species. However, in the model including the effects of climate change, no species, other than the antarctic minke whale, would be able to recover to their pre-exploitation level before the end of the $21^{\text {st }}$ century. The antarctic minke whale would increase rapidly and reach a population size greater than that predicted in the model without climate change (Supplementary Fig. 2). However, this population increase alone would not be sufficient to recover pre-exploitation level for carbon sequestration until 2100. By the end of the century, the whale-mediated carbon pump would reach 
$5.210^{6} \mathrm{tC} . \mathrm{yr}^{-1}$ (range: $2.210^{6}-9.610^{6} \mathrm{tC} . \mathrm{yr}^{-1}$ ), i.e. only half of the pre-exploitation level, under the major influence of antarctic minke whales.

For both models, fin whales were the major contributors until 1959 then antarctic minke whales became the main contributors (Fig. 3) even though they are smaller (sequestering individually less carbon). Owing to their high abundance and low exploitation rate, antarctic minke whales are responsible for roughly $51 \%$ of the total carbon sequestration between 1959 and 2100 in the model without climate change and $66 \%$ in the model with climate change, whereas they account only for $8 \%$ of pre-exploitation sequestration. By comparison, southern right, humpback and blue whales have a minor contribution throughout this period with, on average, $10 \%, 9 \%$ and $8 \%$ respectively between 1959 and 2100.

\section{Deficit of carbon sequestration due to whaling}

Finally, we present the cumulated deficit in carbon sequestration over the whole period (1890 to 2100) due to whaling and under two scenarios of climate change. This deficit was estimated as the difference between the total sequestration (direct and indirect ways) estimated through time under population fluctuations (Fig. 3) and the total sequestration at the carrying capacity (pre-exploitation level). It thus expresses the amount of carbon that has not been sequestered since 1890 and will not be till 2100 due to the combined effects of whaling and climate change. This deficit would reach more than 1Gt.C in 2100 without climate change (Fig. 4a) but 1.2 Gt.C under the more realistic "business as usual" scenario with climate change (Fig. 4b). This deficit is unequally distributed among species with the collapse of the carbon sequestration driven largely by the blue, fin and southern right whales. Conversely, antarctic minke whales provide a surplus of sequestration since 1930, this surplus increasing even further under the climate change scenario to reach $250 \mathrm{Mt} . \mathrm{C}$.

\section{Discussion}

\section{Contribution of whales to the carbon cycle in the Southern Ocean}

To date, some studies have examined the two mechanisms of carbon sequestration by marine megafauna but separately, for a single species or for a small area ${ }^{13,14,34}$. No studies have predicted future carbon sequestration and deficit given changing whale abundances across the Southern Hemisphere under various scenarios. Here, we estimate the amount of carbon sequestered by five southern baleen whale populations from 1890 to 2100 under the joint pressure of whaling (top-down effect) and climate change that will affect the amount of prey available (bottom-up effect). 
The five whale populations at their carrying capacity (pre-exploitation level), represent an annual sequestration potential of $2.510^{5} \pm 0.510^{5} \mathrm{tC} . \mathrm{yr}^{-1}$ via carcasses sinking toward the deep ocean. This estimate is $30 \%$ higher than that of Pershing et al. ${ }^{14}$ who estimate this sequestration at $1.610^{5} \mathrm{tC}^{\mathrm{yr}} \mathrm{yr}^{-}$ ${ }^{1}$ with four additional species (grey whale, sei whale, Bryde's whale, bowhead whale) taken into account. This difference is explained by their lower estimates of carrying capacities. Our estimates were based on hindcasting population dynamics given historical whaling and fitted to current surveys, so are likely more robust estimates of historical carrying capacities.

For the five whale species, the fertilization-induced sequestration reaches up to $10.410^{6} \mathrm{tC}^{\mathrm{yr}} \mathrm{yr}^{-1} \mathrm{with}^{\mathrm{a}}$ range of $3.610^{6}-20.510^{6} \mathrm{tC} . \mathrm{yr}^{-1}$ at carrying capacity or pre-exploitation level. Previous estimate of the indirect sequestration by sperm whales in the Southern Ocean was $0.410^{6} \mathrm{tC}_{\mathrm{yr}}{ }^{-1}$, which is consistent with our results given the population size of sperm whales compared to those of the five species of baleen whales ${ }^{13}$. Given the difference of population size between sperm whales and our five baleen whale species, our results are of the same order of magnitude as this previous assessment. Indeed, these baleen whales represent a biomass about 100 times larger than that of sperm whales and they consume prey (krill) richer in iron (1.7.10-4 Kg iron/Kg dry weight ${ }^{23}$ ) than sperm whales which mainly consume cephalopods (0.75.10-5 Kg iron/Kg dry weight $\left.{ }^{13}\right)$.

We show that the role of whales in carbon sequestration resides more in their capacity to boost other biological carbon pumps (like marine snow) through fertilization than in exporting their own biomass (carcasses) in the deep sea ( $98 \%$ against $2 \%$ of the total flux). Thanks to these two sequestration pathways, the annual carbon flux induced by whales prior to their exploitation (10.6 $10^{6}$ tC. $^{-1} r^{-1}$ on average) was comparable to the carbon fluxes observed in other ecosystems, especially coastal ones, such as mangroves $\left(31.210^{6}-34.410^{6} \mathrm{tC} . \mathrm{yr}^{-1}\right)$ or salt marshes $\left(4.810^{6}-87.210^{6} \mathrm{tC}^{\mathrm{yr}} \mathrm{r}^{-1}\right)$ (Supplementary Table 1).

Due to their long-life cycles, the recovery of many baleen whale populations after over-exploitation has been a very slow process. Therefore, the consequences of whaling extend well beyond the exploitation period and currently limit sequestration of these five baleen whales to $3.410^{6}$ tC. $^{-1} r^{-1}(1.4$ $10^{6}-6.110^{6} \mathrm{tC} . \mathrm{yr}^{-1}$ ), i.e. $32 \%$ of the pre-exploitation level. In the model without climate change, the carbon sink could be restored at $84 \%$ of its pre-exploitation level by 2100 , then reaching $8.910^{6}$ tC.yr $^{-}$

${ }^{1}$. However, the recovery of whale populations and of the carbon pump may be delayed and weakened by climate change ${ }^{17,18}$. This can be explained by changes in the abundance and distribution of krill due to changing primary productivity patterns in the Southern Ocean ${ }^{17}$. Furthermore, the distribution of krill is expected to contract southward due to increasing temperature and reduced sea-ice extent ${ }^{35}$. This could exacerbate even more our results by affecting whale populations predominantly feeding in 
mid-latitudes areas (humpback whales, fin whales and southern right whales) although copepods also make up a large proportion of the diet of southern right whales. Antarctic minke whales and blue whales could benefit most, especially in the Pacific area, of the ice-extent reduction in the Southern Ocean because of their ice-dependency, assuming they can shift their distribution southwards to follow the krill ${ }^{17}$. However, since antarctic minke whales would increase under marked climate change scenario (due to increasing biomass of krill at high latitudes where they are distributed), prey availability for other species may be reduced. Our MICE model includes interspecific competition between the five whale species, and thus accounts for associated effects of changing prey availability on whale recovery given changing whale densities. As a consequence, the recovery of some species is predicted to slow down, with estimated declines again during the $21^{\text {st }}$ century for humpback, fin and southern right whales ${ }^{17}$. As a result, despite a predicted increase of antarctic minke whale populations, the total carbon flux would not return to its pre-exploitation level due to the negative impact of climate change on other species. A negative feedback loop between climate and whale populations could therefore occur in the southern hemisphere. However, these results should be taken with caution as they present several uncertainties.

\section{Limits and uncertainties}

This first estimate of the carbon flux generated by whales is restricted to five baleen species in the southern hemisphere, whereas there are fifteen species of baleen whales globally. Indeed, the number of species considered here was restricted to those included in the whale populations models ${ }^{16,17}$ (i.e. species commercially exploited in Antarctic waters, in most cases feeding predominantly on Antarctic krill, for which enough survey data were available). Therefore, our model may significantly underestimate the importance of carbon sequestration mediated by whales in the Southern Ocean and at global scale by excluding other southern species (Bryde's whale, Pygmy right whale and Dwarf antarctic minke whale), northern species (bowhead whale, gray whale, omuras whale, northern right whale) and toothed whales. Moreover, the indirect carbon sequestration mechanism was only considered during the summer period, when the whales are located in the Southern Ocean. During winter, they migrate towards tropical regions to breed. However, other nutrients (nitrogen, phosphorus) also excreted by whales ${ }^{34}$ limit phytoplankton productivity in these areas ${ }^{21}$. Thus, they could indirectly promote carbon sequestration during the breeding season and migration. The carbon sequestration induced by whales is therefore likely to be much larger and extends towards the tropics.

Estimates of carbon sequestered via carcasses are subject to several uncertainties. First, we assume that the biomass-carbon conversion does not change with carcass degradation. However, not all 
tissues have the same carbon concentration ${ }^{36}$ and some (fat tissue, muscle) may be consumed primarily by scavengers ${ }^{37}$. In order to gain precision, it seems essential to determine the carbon level in the different types of tissue (bone, muscle, blubber, viscera) for each species. On the other hand, the proportion of biomass reaching the deep ocean before being consumed or remineralised is uncertain and probably highly variable, depending on the presence of scavengers or currents for example. Finally, these migratory species experience significant weight variations during the year ${ }^{38}$ : they may gain several tonnes during the summer and be considerably thinner at the end of the breeding season. The amount of carbon sequestered therefore depends on the seasonality of natural mortality, which is not taken into account in our study.

The main uncertainty in our estimated indirect sequestration is the amount of bioavailable iron provided by whales at sea surface. First, iron concentration values in whale faeces were obtained with few replicates, and those of antarctic minke whales were estimated from available data for other species. Surprisingly, the iron concentration in southern right whale faeces ${ }^{27}$ is higher than that of other species, whereas it would be expected to be lower. Indeed, the proportion of krill, an iron accumulator, in their diet is lower compared to other species ${ }^{23}$. This may be indicative of high intraspecies, temporal or spatial variability in faecal iron concentration. On the other hand, individual variability within species has also been ignored. Iron retention in the body varies with age and reproductive status ${ }^{39}$. To address this issue, the population could be divided into different categories (juveniles, adults, pregnant or lactating females) and the iron concentration in the faeces could be estimated for each category.

Secondly, to estimate the response of phytoplankton to the iron supply, the fraction of iron contained in faeces, which is finally incorporated by phytoplankton, needs to be estimated. This is influenced by both bioavailability of the iron supply and the fate of this iron. On the one hand, iron bioavailability in the ocean is influenced by many processes (dissolved or particulate form, degree of oxidation, complexation with organic ligands, etc.) ${ }^{40}$. No studies have estimated the bioavailable fraction of iron released by whales. We considered the dissolved iron or the iron dissolving in the first 12 hours to be bioavailable but our values are probably underestimated. Indeed, iron particles are small (a few micrometres) and their density is close to water density so they sink slowly and could remain for several days in the euphotic zone where dissolution may continue ${ }^{41}$. In addition, the dissolution experiment of Ratnarajah et al. ${ }^{41}$ was conducted in the dark. Light can increase dissolution (photodissolution) ${ }^{42,43}$. On the other hand, both heterotrophic bacteria and autotrophic phytoplankton depend on the available iron pool for growth. So, auto- and heterotrophs could compete for iron when dissolved organic carbon limitation of bacterial growth is alleviated ${ }^{44}$. However, heterotrophic bacteria can also recycle iron, increasing iron solubility and availability by recycling particulate iron into 
322

323

324

325

326

327

328

329

330

331

332

333

334

335

336

337

338

339

340

341

342

343

344

345

346

347

348

349

350

351

352

353

354

dissolved iron, producing organic ligands binding to the iron and increasing iron suspension and bioavailability ${ }^{45}$.

These various processes can either increase or decrease the availability of iron for phytoplankton making difficult to assess the bioavailability and fate of iron supplied by whales in the euphotic zone. Therefore, a better estimation of the amount of iron released by the different whale species and its availability for phytoplankton seems essential to precisely quantify the indirect sequestration pathway. Finally, to quantify the additional carbon sequestered owing to iron inputs by whales, experimental measurements of carbon exported at 200 meters in response to iron addition were used ${ }^{33}$. These data may be a source of overestimation since we assume that all carbon exported at 200 metres will sediment and be sequestered. However, organic matter may be remineralised before reaching the deep ocean ${ }^{46}$ or be broken down into smaller particles that sink more slowly ${ }^{47}$.

\section{Importance of whale diversity for carbon sequestration}

We studied five species of baleen whales, diverse in size, longevity and life cycles, each contributing differently to the two carbon sequestration pathways. Sequestration via carcasses sinking is mainly supported by the most massive species such as blue and fin whales, which can reach approximately 117 and 65 tonnes per individual, respectively. In contrast, the indirect sequestration pathway depends mainly on the smaller but more abundant antarctic minke whale. This is explained by the fact that prey consumption (determining the amount of faeces) is a hypo-allometric function of body mass ${ }^{48}$, whereas in the case of carcasses, the carbon sequestration is a linear function of body mass. Considering that biomass and abundance are the two components that determine the relative contribution of a species to carbon sequestration, the direct pathway is more dependent on individual body mass while the indirect pathway is more dependent on the number of individuals. Southern right whales are also weaker contributors to the direct sequestration pathway because of their tendency to float after death. Conversely, their strong iron concentration in faeces make them very efficient in sequestering carbon via the fertilization pathway.

This complementarity between species, resulting from the diversity of their traits, helps to maintain the different sequestration pathways. More generally, this functional complementarity is key to support ecosystem multifunctionality ${ }^{49,50}$ and increases the associated ecosystem services ${ }^{51}$. Moreover, it is generally considered that the stability of a system increases with the diversity of its components; this is the portfolio effect. In ecology, this results into a positive diversity-stability relationship: the specific diversity of a community stabilises its functioning through time and under disturbances ${ }^{52}$. Thus, ecological processes performed by a diverse community are more stable over 
time and less subject to fluctuations than individual species ${ }^{53,54}$. The two main factors in this relationship: the asynchrony between populations, and the average stability of each population ${ }^{54}$. In our case, the important increase in antarctic minke whales, which have a higher breeding rate and have been less exploited, along with the over-exploitation of other species, is stabilizing the overall abundance of Southern Ocean whales. Thus, antarctic minke whales maintain, at least partially, the carbon sink and limit the loss of sequestration under over-exploitation. Their increase throughout the $21^{\text {st }}$ century is also a key resilience factor since they allow a faster recovery of carbon flux towards its historical value. However, even if the carbon flux partially recovers at the end of the century, the relative species contributions to the carbon flux are very different from those of the pre-exploitation period, especially in the model including climate change. Thus, we have a functional recovery but from an ecological and conservation point of view the southern whale community is not returning to its former state.

\section{Restoring whale populations: a Natural Climate Solution?}

To consider whale population restoration as a Natural Climate Solution (NCS), several criteria must be met: effectiveness, the presence of co-benefits and the limitation of associated disadvantages, and the governability, i.e. the ability to implement this solution, while managing the conflicts and benefits generated by its implementation ${ }^{55}$.

To maintain the global warming at a maximum of $+2^{\circ} \mathrm{C}$, total emissions must be less than $81010^{9} \mathrm{tCO}_{2^{-}}$ eq between 2016 and $2100^{6}$ and achieve zero net emissions by $2075^{56}$. This implies not only reducing GHG emissions but also offsetting unavoidable emissions. For example, in the field of road transport, our annual emissions are expected to decrease from $5.7510^{9} \mathrm{tCO}_{2}$-eq.yr-1 in 2015 to $2.610^{9} \mathrm{tCO}_{2}$-eq.yr ${ }^{1}$ in 2050 thanks to energy efficiency gains and cleaner fuels ${ }^{57}$. By 2050, southern baleen whales should be able to offset $0.7 \%$ of these persistent road transport emissions by sequestering an average of 17 $10^{6} \mathrm{tCO}_{2}$-eq.yr ${ }^{-1}$. In addition, by $2100, \mathrm{GHG}$ emissions from all transports should not exceed $1.810^{9}$ $\mathrm{tCO}_{2}$-eq. $\mathrm{yr}^{-1}{ }^{57}$. According to the model predictions without climate change, these remaining emissions could be compensated up to $1.8 \%$ by southern baleen whales, which would sequester about $32.610^{6}$ $\mathrm{tCO}_{2} \cdot \mathrm{yr}^{-1}$ in 2100 . On the other hand, if climate change continues to follow a RCP 8.5 scenario ${ }^{20}$, southern whales would be able to sequester only $1910^{6} \mathrm{tCO}_{2} \cdot \mathrm{yr}^{-1}$, offsetting $1.1 \%$ of global transport emissions in 2100. Moreover, if they are managed to be restored to their pre-exploitation levels by the end of the $21^{\text {st }}$ century, they could compensate up to $2.1 \%$ of these emissions. Thus, although many whale populations have been severely depleted by whaling, restoring their populations could contribute, even marginally, to achieving our carbon neutrality objectives. 
In addition, the presence of whales is associated with many other benefits, promoting the good health of ecosystems and some services to human societies. Indeed, whale carcasses are an essential source of food for abyssal ecosystems ${ }^{10,58}$. Thanks to their enriching action on their planktonic environment, they can be described as ecosystem engineers, favouring lower trophic levels ${ }^{59}$. Whales enhance krill growth through increased phytoplankton production ${ }^{39}$, which also participates very efficiently in carbon sequestration through the production of fast-sinking particulate faeces ${ }^{24}$. In addition, whales have a strong cultural and aesthetic value: tourism associated with whale watching generates more than US\$2.5 billion per year and 19,000 jobs worldwide ${ }^{60}$. The recovery of their populations could therefore enable the development of a sustainable tourism economy. Thus, restoring whale populations would promote some socio-economic co-benefits in the Southern Ocean, whether in terms of mitigating climate change, maintaining biodiversity, or tourism activities.

In addition to the moratorium established in 1986 by the International Whaling Commission (IWC), some further measures can be taken to promote the recovery of whale populations. Indeed, several anthropogenic activities continue to threaten whales. Ship strikes are now among the main causes of mortality ${ }^{61}$. Noise generated by boats also alters whale mortality and reproduction rates by modifying key behaviours related to feeding, reproduction or communication ${ }^{62}$. In 2016, the IWC created a strategic plan to monitor collisions between cetaceans and vessels in order to develop approaches and solutions to achieve a permanent reduction in ship strikes by 2020. Although effective in terms of mortality reduction, the restriction of maritime routes and fishing zones as well as the reduction of authorised speed can create conflicts of interest with fishing and maritime transport ${ }^{63}$. However, the main threat to the recovery of whale populations in the coming years may likely be climate change 17,18 , including the increased spread of disease ${ }^{19}$ and the decrease in krill prey density and southward contraction of geographic distributions ${ }^{35}$. Although krill is not currently overexploited ${ }^{64}$, the demand has been increasing since the 2000 s and is expected to increase in the coming years ${ }^{35}$. Continuing to promote sustainable exploitation of krill in the Southern Ocean could therefore be a main lever for actions to preserve whale populations and their associated services. The restoration of whale populations in the Southern Ocean must therefore be accompanied by various concrete measures to manage this ecosystem. We can conclude that the restoration of baleen whale populations meet all criteria in terms of carbon sequestration effectiveness, co-benefits and governability to be considered as a NCS.

More generally, other species including marine mammals, birds and fish could generate a substantial carbon pump through similar mechanisms. A more ambitious NCS could therefore emerge, based on various vertebrate species. However, populations should be at their maximum size in order to benefit from the full potential of these NCSs. Identifying and quantifying these NCSs could motivate the 
protection of the oceans to reach $30 \%$ coverage by 2030 , the new target proposed by the United Nations ${ }^{65}$. In this way, restoring marine vertebrate populations could contribute to achieving our climate objectives while generating other services beneficial to the functioning of the biosphere and the well-being of human societies ${ }^{66,67}$.

\section{Materials and Methods}

\section{Model of intermediate complexity for ecosystem assessment}

We used outputs from a Southern Hemisphere spatial 'Model of Intermediate Complexity for Ecosystem Assessments' (MICE) for phytoplankton, krill (Euphausia superba) and five baleen whale species, which estimates whale population trajectories from 1890 to 2100 . The model uses the most up-to-date catch records from the International Whaling Commision (IWC) that account for data falsification and errors. These data thus represent the most updated catch series, and our model estimates represent the most up to date population trajectories for the main baleen whales in the Southern Hemisphere. MICE are well-suited for developing predictions of large-scale system dynamics requiring an understanding of ecological interactions between species and processes, by restricting focus to key ecosystem components, and through parameter estimation fitted to data and sensitivity analyses, can account for key uncertainties. The model uses delay-difference equations to describe whale dynamics at annual seasonal time-steps, linked to an age-structured population model for krill (see Tulloch et al. ${ }^{16,17}$ for detailed description of equations and parameter settings for the base model). Prey dynamics (krill and copepods) are linked to primary productivity outputs from a coupled NutrientPhytoplankton-Zooplankton-Detritus model (NPZD). The model thus includes two-way interactions between whales and prey, with bottom-up environmental forcing and top-down consumption of changing prey base by whales. As the model is restricted to southern whale populations, we considered that whales feed exclusively on krill and in smaller proportion on copepods.

Two versions of the model were used, a climate-forced version linking prey dynamics to future changing temperature and Chl-a outputs from the NPZD model driven by Representative Concentration Pathways (RCP) 8.5 adopted by the Intergovernmental Panel on Climate Change (IPCC) Fifth Assessment Report (AR5) ${ }^{56}$, and another where these links to changing environmental conditions were excluded. Both models were fitted to an index of abundance from available surveys for the five whale species and first simulate historical whale trajectories from 1890-2013 for two regions (Pacific, and Atlantic/Indian), and two seasons (feeding and breeding), driven largely by the historical commercial whaling records from the IWC. 
We obtained the following outputs from the two MICE models to input into our model: (i) Time series of population abundance estimates from 1890-2100, for females only, for each species and Area of the model ( $P=$ Southern Hemisphere Pacific, and $A=$ Southern Hemisphere Atlantic/Indian) and (ii) Biological parameters and carrying capacity estimates for each species in the model (Supplementary Table 2).

\section{Carbon sequestration by whale carcasses}

The weight of whales, and by extension the amount of carbon they contain, depends on their age. The age structure of the population in a given year, i.e. the number of individuals in an age class, was constructed using demographic parameters for each species derived from the MICE model (Supplementary Table 2). The population abundance numbers provided by the MICE model correspond to mature females. To obtain the total number, the number of males $\left(E_{\text {male }}\right)$ is estimated from the number of females $\left(E_{\text {female }}\right)$ and the sex ratio $(q)$ :

$E_{\text {tot }}=E_{\text {female }}+E_{\text {male }} \quad ; \quad E_{\text {female }}=q \cdot E_{\text {tot }} ; \quad E_{\text {male }}=(1-q) \cdot E_{\text {tot }} \Rightarrow E_{\text {male }}=\frac{(1-q)}{q} \cdot E_{\text {female }}$

For each gender, the number of individuals $(N)$ in each age class $(a)$ between birth and maximum age $(z)$ is then calculated from the number $(E)$ of adult individuals between the age of maturity $(T)$ and maximum age $(z)$ and the survival rate $\left(S\right.$ or $\left.S_{j u v}\right)$. A distinction is made between the survival rate of individuals under one year old $\left(S_{j u v}\right)$ and that of individuals over one-year old $(S)$. These rates are species-specific (Supplementary Table 2), considered constant and identical for males and females. The number of individuals of a given year class (individuals aged $a$ ) is written as a function of the number of individuals aged $T$ :

$\forall a \in] 0, z] \quad N_{a+1}=S \cdot N_{a} \Rightarrow N_{a}=S^{a-T} \cdot N_{T} \quad ; \quad$ For $\quad a=0, \quad N_{0}=S_{j u v}^{-1} \cdot S^{1-T} \cdot N_{T}$ The number of individuals in $T$ years can be found with the parameters of the model:

$$
\sum_{a=T}^{z} N_{a}=E \quad \Rightarrow \quad N_{T} \cdot \sum_{a=T}^{z} S^{a-T}=E \quad \Rightarrow \quad N_{T}=\frac{E}{\sum_{a=T}^{z} S^{A-T}}
$$

Thus, the age structure of the population can be written as a function of $N_{T}$ :

$$
N_{0}=S_{j u v}^{-1} \cdot S^{1-T} \cdot N_{T} ; \quad N_{1}=S^{1-T} \cdot N_{T} \quad \cdots \quad N_{T-1}=S^{-1} \cdot N_{T} \quad ; \quad N_{T} \quad ; \quad N_{T+1}=S \cdot N_{T} \cdots \quad N_{z}=S^{z-T} \cdot N_{T}
$$

This age structure calculation is applied every year from 1890 to 2100 . We assume that age structure does not vary over time. Indeed, the mass of individuals is almost constant in adulthood. It is therefore assumed that no adult year class is more impacted by whaling than another. Among juveniles, very few catches have been reported for the whale species in this study ${ }^{68}$. 
In order to calculate the number of individuals dying naturally each year, the natural mortality rate (1$S$ or $1-S_{j u v}$ ) was applied to the numbers in each age class (Supplementary Table 2). This gives the number of individuals dying per age class in a given year.

To obtain the biomass of an age class, the number of individuals in this class was multiplied by the corresponding individual body mass. The mass of individuals at each age follows the Von Bertalanffy equation, whose parameters, depend on both species and sex ${ }^{14}$ (Supplementary Table 3). Let $a$ the age, $m_{\text {inf }}$ the maximum size of individuals, $k$ the growth rate and $a_{0}$ the theoretical age at which the mass is zero, the mass $m$ of an individual aged $a$ is:

$$
m(a)=m_{\text {inf }}\left(1-e^{-k\left(a-a_{0}\right)}\right)
$$

The total population biomass $\left(B_{\text {tot }}\right)$ was calculated from the biomass of each age class $\left(B_{a}\right)$ as follows:

$$
B_{\text {tot }}=\sum_{a=0}^{z} B_{a} \quad \text { with } B_{a}=m_{\text {female }}(a) \cdot N_{\text {female }, a}+m_{\text {male }}(a) \cdot N_{\text {male }, a}
$$

To assess the amount of carbon sequestered by the sinking of whale carcasses, the biomass was converted into carbon mass. Several estimates of carbon content in whale tissues are available: $10.5 \%$ ${ }^{36}$ and $15 \%{ }^{9}$. A carbon rate of $12.5 \% \pm 2.5 \%$ was thus used, assuming that this rate is identical for all individuals without distinction of species, sex or age. To calculate the amount of carbon, the biomass was multiplied by this carbon rate.

The fate of the carcasses depends on several factors. Attacks by predators such as killer whales (Orcinus orca) are rare and very rarely lethal ${ }^{69,70}$. Most dead individuals should therefore sink and sequester carbon in the deep sea. However, carcasses do not sink in their entirety to the ocean floor because they are partly consumed by scavengers like sharks ${ }^{71}$ or killer whales ${ }^{72}$ or degraded by microorganisms. It was estimated that between $50 \%$ and $90 \%$ of a carcass reaches the ocean floor ${ }^{73}$. The conservative estimate of $50 \%$ has been used for all species except southern right whales, which tend to float after death due to a higher proportion of blubber ${ }^{74}$. For southern right whales we considered that only $10 \%$ of carcass biomass is sequestered in the deep sea ${ }^{14}$.

\section{Indirect carbon sequestration via fertilization}

Whales play also a role in the carbon cycle through their ability to fertilize the ocean with nutrients contained in their faeces (Fig. 1b). Migratory baleen whales spend the summer in the Southern Ocean where food is abundant. During their migration and the breeding season in the tropics they feed only in small quantities ${ }^{75}$. Thus, we considered carbon sequestration via fertilization only in the 
514

515

516

517

518

519

520

521

522

523

524

525

526

527

528

529

530

531

532

533

534

535

536

537

538

539

540

541

Southern Ocean, the main feeding ground for migratory baleen whales that eat krill. Several estimates of daily prey consumption (noted $R$ in $\mathrm{Kg}$ ) exist ${ }^{48}$. Owen et al. ${ }^{76}$ recommend using the allometric expression of consumption as a function of whale body mass with the parameters provided by Innes et al. ${ }^{77}$ to obtain an upper bound, and using the formula based on metabolic rate to obtain a lower bound, with the expression of the ADMR (Average Daily Metabolic Requirement) given by Boyd ${ }^{76}$. Thus, the estimates of minimum (equation 7), maximum (equation 8) and average (equation 9) daily consumption were defined as follows:

$$
R j_{\min }=\frac{A D M R}{0.8 .3900} \quad ; \quad A D M R=2529.1 \mathrm{~m}^{0.524}
$$

with $\mathrm{m}$ the body mass $(\mathrm{Kg})$, the energy intake from the crustaceans $(3900(\mathrm{KJ} / \mathrm{Kg}))$ and 0.8 the assimilated proportion in relation to the ingested mass.

$$
\begin{gathered}
R j_{\text {max }}=A . m^{B} \quad ; \quad A=0.42 \text { et } B=0.67 \\
R j_{\text {mean }}=\frac{R j_{\text {min }}+R j_{\text {max }}}{2}
\end{gathered}
$$

Consumption of prey during the summer season accounts for $83 \%$ of the annual consumption ${ }^{48,75}$. Thus, the quantity of prey consumed yearly in the Southern Ocean is written as:

$$
R_{S O}=0.83 \cdot 365 \cdot R j
$$

One part of the prey ingested (25\%) is directly used by the whale for its metabolism. Only $75 \%$ of the wet weight of ingested prey is therefore defecated ${ }^{13,39}$. Furthermore, since prey consumption depends on the mass of individuals, the age structure was reused to obtain the number and biomass of individuals in each age class. Finally, the annual amount of faeces defecated by all individuals aged $a$ $\left(D_{a}\right)$ is calculated as follows:

$$
D_{a}=0.75 \cdot R_{S O}(a) \cdot N_{a}
$$

These faecal masses were then summed for all age classes to obtain the total amount of faeces produced by each whale species in the Southern Ocean $\left(D_{t o t}\right)$.

$$
D_{\text {tot }}=\sum_{a=0}^{z} D_{a}
$$

To assess the amount of iron released by whales, experimental measurements of iron concentration in the faeces of blue, humpback and fin whales conducted by Nicol et al. ${ }^{23}$ were used (Supplementary Table 4). For humpback and fin whales, only a mean value was given. We applied the Taylor's law ${ }^{78}$ to estimate the associated variance $(V)$ of a biological measure from its mean $(\mu)$ using the power 


$$
m_{\text {carbon }}=\frac{12 . m_{\text {iron }}}{55,8} \frac{C_{\text {exported }}}{D F e_{\text {additional }}}
$$
bioavailable iron released by whales in the euphotic zone.

$$
\frac{C_{\text {exported }}}{D F e_{\text {additional }}}=5.10^{4}{\mathrm{~mol} . \mathrm{mol}^{-1}}^{-1}
$$
the additional amount of sequestered carbon $\left(m_{\text {carbon }}\right.$ in $\left.\mathrm{g}\right)$ is written as:

The need for whales to return to the surface to breathe and the limited duration of their dives suggest that all faeces are released into the euphotic zone ${ }^{80}$. However, only one part of the iron defecated can benefit to phytoplankton productivity. Indeed, iron can take different chemical forms and many factors influence its bioavailability (dissolved or particulate form, degree of oxidation, complexation with organic ligands). Iron in dissolved form $(<0.2 \mu \mathrm{m})$ is generally considered to be the most bioavailable fraction ${ }^{81}$. More than $87 \%$ of the iron in whale faeces is in particulate form $(>0.2 \mu \mathrm{m}){ }^{41}$. However, particulate iron can dissolve over time and become more bioavailable. The proportion of bioavailable iron in whale faeces was estimated to be $12.2 \%$ after 12 hours based on the results of a dissolution experiment of particulate iron from whale faeces ${ }^{41}$. This rate was used to obtain the amount of

The iron provided to the sea surface by the whales stimulates phytoplankton growth. However, not all of the fixed carbon is sequestered in the deep sea because a part is rapidly remineralised. Several studies have measured the amount of carbon sequestered in response to natural iron input in the euphotic zone ${ }^{33,82}$. Lavery et al. ${ }^{13}$ use the average molar ratio between the additional carbon sequestered at 200 metres and the additional dissolved iron from two natural enrichment studies ${ }^{33,82}$ :

Knowing the molar mass of iron ( $55.8 \mathrm{in} \mathrm{g} / \mathrm{mol})$, carbon $(12 \mathrm{in} \mathrm{g} / \mathrm{mol})$ and the mass of iron $\left(m_{\text {iron }}\right.$ in $\left.\mathrm{g}\right)$, 
572

573

574

575

576

577

578

579

580

581

582

583

584

585

586

587

588

589

590

591

592

593

594

595

596

\section{References}

1. Friedlingstein, P. et al. Global Carbon Budget 2019. Earth Syst. Sci. Data 11, 1783-1838 (2019).

2. Hoegh-Guldberg, O. et al. The human imperative of stabilizing global climate change at $1.5^{\circ} \mathrm{C}$. Science 365, eaaw6974 (2019).

3. Xu, C., Kohler, T. A., Lenton, T. M., Svenning, J.-C. \& Scheffer, M. Future of the human climate niche. Proc Natl Acad Sci USA 117, 11350-11355 (2020).

4. UNFCCC. United Nations Framework Convention on Climate Change, COP 21 Climate Agreement (UNFCCC, Paris). (2015).

5. McLaren, D. A comparative global assessment of potential negative emissions technologies. Process Saf Environ 90, 489-500 (2012).

6. Realmonte, G. et al. An inter-model assessment of the role of direct air capture in deep mitigation pathways. Nat Commun 10, 3277-3289 (2019).

7. Griscom, B. W. et al. Natural climate solutions. Proc Natl Acad Sci USA 114, 11645-11650 (2017).

8. Seddon, N., Turner Beth, B. P., Alexandre Chausson, P. \& Cécile A. J. Girardin. Grounding naturebased climate solutions in sound biodiversity science. Nat. Clim. Change 9, 82-87 (2019).

9. Bar-On, Y. M., Phillips, R. \& Milo, R. The biomass distribution on Earth. Proc Natl Acad Sci USA $115,6506-6511(2018)$.

10. Roman, J. et al. Whales as marine ecosystem engineers. Frontiers in Ecology and the Environment 12, 377-385 (2014).

11. Smetacek, V., Assmy, P. \& Henjes, J. The role of grazing in structuring Southern Ocean pelagic ecosystems and biogeochemical cycles. Antarctic Science 16, 541-558 (2004).

12. Van Franeker, J. A., Bathmann, U. V. \& Mathot, S. Carbon fluxes to antarctic top predators. Deep Sea Research Part II: Topical Studies in Oceanography 44, 435-455 (1997).

13. Lavery, T. J. et al. Iron defecation by sperm whales stimulates carbon export in the Southern Ocean. Proc. R. Soc. B 277, 3527-3531 (2010). 
14. Pershing, A. J., Christensen, L. B., Record, N. R., Sherwood, G. D. \& Stetson, P. B. The Impact of Whaling on the Ocean Carbon Cycle: Why Bigger Was Better. PLoS ONE 5, e12444 (2010).

15. Christensen, L. B. Marine mammal populations: Reconstructing historical abundances at the global scale. vol. 14 (2006).

16. Tulloch, V. J. D., Plagányi, É. E., Matear, R., Brown, C. J. \& Richardson, A. J. Ecosystem modelling to quantify the impact of historical whaling on Southern Hemisphere baleen whales. Fish Fish 19, $117-137$ (2018).

17. Tulloch, V. J. D., Plagányi, É. E., Brown, C., Richardson, A. J. \& Matear, R. Future recovery of baleen whales is imperiled by climate change. Glob Change Biol 25, 1263-1281 (2019).

18. Albouy, C. et al. Global vulnerability of marine mammals to global warming. Sci Rep 10, 548-560 (2020).

19. Sanderson, C. E. \& Alexander, K. A. Unchartered waters: Climate change likely to intensify infectious disease outbreaks causing mass mortality events in marine mammals. Glob Change Biol 00, 1-18 (2020).

20. Schwalm, C. R., Glendon, S. \& Duffy, P. B. RCP8.5 tracks cumulative CO2 emissions. PNAS 117, 19656-19657 (2020).

21. Moore, C. M. et al. Processes and patterns of oceanic nutrient limitation. Nature Geosci 6, 701710 (2013).

22. Boyd, P. W., Claustre, H., Levy, M., Siegel, D. A. \& Weber, T. Multi-faceted particle pumps drive carbon sequestration in the ocean. Nature 568, 327-335 (2019).

23. Nicol, S. et al. Southern Ocean iron fertilization by baleen whales and Antarctic krill: Whales, Antarctic krill and iron fertilization. Fish Fish 11, 203-209 (2010).

24. Cavan, E. L. et al. The importance of Antarctic krill in biogeochemical cycles. Nat Commun 10, 4742 (2019).

25. Ratnarajah, L., Bowie, A. R., Lannuzel, D., Meiners, K. M. \& Nicol, S. The Biogeochemical Role of Baleen Whales and Krill in Southern Ocean Nutrient Cycling. PLoS ONE 9, e114067 (2014). 
26. Friedlaender, A. et al. Whale distribution in relation to prey abundance and oceanographic processes in shelf waters of the Western Antarctic Peninsula. Mar. Ecol. Prog. Ser. 317, 297-310 (2006).

27. Wing, S. et al. Seabirds and marine mammals redistribute bioavailable iron in the Southern Ocean. Mar. Ecol. Prog. Ser. 510, 1-13 (2014).

28. Wing, S. R. et al. $856 \mathrm{Fe}$ in seabird guano reveals extensive recycling of iron in the Southern Ocean ecosystem. Limnology and Oceanography 62, 1671-1681 (2017).

29. Graham, N. A. J. et al. Seabirds enhance coral reef productivity and functioning in the absence of invasive rats. Nature 559, 250-253 (2018).

30. Hjerne, O. \& Hansson, S. The Role of Fish and Fisheries in Baltic Sea Nutrient Dynamics. Limnol Oceanogr 47, 1023-1032 (2002).

31. Vanni, M. J., Boros, G. \& McIntyre, P. B. When are fish sources vs. sinks of nutrients in lake ecosystems? Ecology 94, 2195-2206 (2013).

32. Allgeier, J. E., Burkepile, D. E. \& Layman, C. A. Animal pee in the sea: consumer-mediated nutrient dynamics in the world's changing oceans. Glob Change Biol 23, 2166-2178 (2017).

33. Blain, S. et al. Effect of natural iron fertilization on carbon sequestration in the Southern Ocean. Nature 446, 1070-1074 (2007).

34. Roman, J. \& McCarthy, J. J. The Whale Pump: Marine Mammals Enhance Primary Productivity in a Coastal Basin. PLoS ONE 5, e13255 (2010).

35. Atkinson, A. et al. Krill ( Euphausia superba ) distribution contracts southward during rapid regional warming. Nature Clim Change 9, 142-147 (2019).

36. Jelmert, A. \& Oppen-Berntsen, D. O. Whaling and Deep-Sea Biodiversity. Conserv Biol 10, 653654 (1996).

37. Curtis, T. H. et al. Observations on the behavior of white sharks scavenging from a whale carcass at Point Reyes, California. Calif Fish Game 92, 113-124 (2006). 
38. Víkingsson, G. A. Body condition of fin whales during summer off Iceland. in Whales, seals, fish and man (eds. Blix, A. S., Walløe, L. \& Ulltang, Ø.) vol. 4 361-369 (Elsevier Science, 1995).

39. Lavery, T. J. et al. Whales sustain fisheries: Blue whales stimulate primary production in the Southern Ocean. Mar Mam Sci 30, 888-904 (2014).

40. Norman, L., Cabanesa, D. J. E., Blanco-Ameijeiras, S., Moisset, S. A. M. \& Hassler, C. S. Iron Biogeochemistry in Aquatic Systems: From Source to Bioavailability. CHIMIA 68, 764-771 (2014).

41. Ratnarajah, L. et al. Physical speciation and solubility of iron from baleen whale faecal material. Mar Chem 194, 79-88 (2017).

42. Wells, M. L., Mayer, L. M., Donard, O. F. X., de Souza Sierra, M. M. \& Ackelson, S. G. The photolysis of colloidal iron in the oceans. Nature 353, 248-250 (1991).

43. Boyd, P. W., Ellwood, M. J., Tagliabue, A. \& Twining, B. S. Biotic and abiotic retention, recycling and remineralization of metals in the ocean. Nature Geoscience 10, 167-173 (2017).

44. Fourquez, M. et al. Microbial Competition in the Subpolar Southern Ocean: An Fe-C Colimitation Experiment. Front. Mar. Sci. 6, (2020).

45. Boyd, P. W., Ibisanmi, E., Sander, S. G., Hunter, K. A. \& Jackson, G. A. Remineralization of upper ocean particles: Implications for iron biogeochemistry. Limnol. Oceanogr. 55, 1271-1288 (2010).

46. Pavia, F. J. et al. Shallow particulate organic carbon regeneration in the South Pacific Ocean. Proc Natl Acad Sci USA 116, 9753-9758 (2019).

47. Briggs, N., Dall'Olmo, G. \& Claustre, H. Major role of particle fragmentation in regulating biological sequestration of $\mathrm{CO}_{2}$ by the oceans. Science $367,791-793$ (2020).

48. Barlow, J., Kahru, M. \& Mitchell, B. Cetacean biomass, prey consumption, and primary production requirements in the California Current ecosystem. Mar. Ecol. Prog. Ser. 371, 285-295 (2008).

49. Godoy, O., Gómez-Aparicio, L., Matías, L., Pérez-Ramos, I. M. \& Allan, E. An excess of niche differences maximizes ecosystem functioning. Nature Communications 11, 4180 (2020). 
50. Schuldt, A. et al. Biodiversity across trophic levels drives multifunctionality in highly diverse forests. Nat Commun 9, 2989 (2018).

51. Cardinale, B. J. et al. Biodiversity loss and its impact on humanity. Nature 486, 59-67 (2012).

52. Craven, D. et al. Multiple facets of biodiversity drive the diversity-stability relationship. Nature Ecology \& Evolution 2, 1579-1587 (2018).

53. Schindler, D. E. et al. Population diversity and the portfolio effect in an exploited species. Nature 465, 609-612 (2010).

54. Thibaut, L. M. \& Connolly, S. R. Understanding diversity-stability relationships: towards a unified model of portfolio effects. Ecol Lett 16, 140-150 (2013).

55. Gattuso, J.-P. et al. Ocean Solutions to Address Climate Change and Its Effects on Marine Ecosystems. Front. Mar. Sci. 5, 337-355 (2018).

56. IPCC. Global Warming of $1.5^{\circ} \mathrm{C}$. An IPCC Special Report on the impacts of global warming of $1.5^{\circ} \mathrm{C}$ above pre-industrial levels and related global greenhouse gas emission pathways, in the context of strengthening the global response to the threat of climate change, sustainable development, and efforts to eradicate poverty. (2018).

57. Keramidas, K. et al. Global energy and climate outlook 2018 sectoral mitigation options towards a low-emissions economy: global context to the EU strategy for long-term greenhouse gas emissions reduction. (2018).

58. Smith, C. R., Glover, A. G., Treude, T., Higgs, N. D. \& Amon, D. J. Whale-Fall Ecosystems: Recent Insights into Ecology, Paleoecology, and Evolution. Annu. Rev. Mar. Sci. 7, 571-596 (2015).

59. Jones, C. G., Lawton, J. H. \& Shachak, M. Organisms as ecosystem engineers. Oikos 69, 373-388 (1994).

60. Cisneros-Montemayor, A. M., Sumaila, U. R., Kaschner, K. \& Pauly, D. The global potential for whale watching. Marine Policy 34, 1273-1278 (2010).

61. Schoeman, R. P., Patterson-Abrolat, C. \& Plön, S. A Global Review of Vessel Collisions With Marine Animals. Front. Mar. Sci. 7, 292 (2020). 
699

700

701

702

703

704

705

706

707

708

709

710

711

712

713

714

715

716

717

718

719

720

721

722

723

724

62. Parsons, E. C. M. The Negative Impacts of Whale-Watching. J Mar Bio/ 2012, 1-9 (2012).

63. Koubrak, O., VanderZwaag, D. L. \& Worm, B. Saving the North Atlantic right whale in a changing ocean: Gauging scientific and law and policy responses. Ocean Coast Manag 105109, (2020).

64. FAO. The State of World Fisheries and Aquaculture 2020: Sustainability in action. (FAO, 2020). doi:10.4060/ca9229enAlso Available in:Chinese Spanish Arabic French Russian.

65. Visconti, P. et al. Protected area targets post-2020. Science 364, 239-241 (2019).

66. Tavares, D. C., Moura, J. F., Acevedo-Trejos, E. \& Merico, A. Traits Shared by Marine Megafauna and Their Relationships With Ecosystem Functions and Services. Front. Mar. Sci. 6, 262-274 (2019).

67. Riisager-Simonsen, C., Rendon, O., Galatius, A., Olsen, M. T. \& Beaumont, N. Using ecosystemservices assessments to determine trade-offs in ecosystem-based management of marine mammals. Conserv Biol (2020) doi:10.1111/cobi.13512.

68. Allison, C. IWC individual and summary catch databases. (2013).

69. Jefferson, T. A., Stacey, P. J. \& Baird, R. W. A review of Killer Whale interactions with other marine mammals: predation to co-existence. Mamm Rev 21, 151-180 (1991).

70. Ford, J. K. B. \& Reeves, R. R. Fight or flight: antipredator strategies of baleen whales. Mammal Review 38, 50-86 (2008).

71. Lea, J. S. E., Daly, R., Leon, C. \& Daly, C. A. K. Life after death: behaviour of multiple shark species scavenging a whale carcass. Mar Freshw Res 70, 302-306 (2018).

72. Whitehead, H. \& Reeves, R. Killer whales and whaling: the scavenging hypothesis. Biol Lett 1, 415-418 (2005).

73. Smith, C. R. \& Baco, A. R. Ecology of whale falls at the deep-sea floor. Oceanogr Mar Biol 44, 311-354 (2003).

74. Lockyer, C. Body weights of some species of large whales. ICES J Mar Sci 36, 259-273 (1976).

75. Lockyer, C. et al. Growth and energy budgets of large baleen whales from the southern hemisphere. XF2006134403 FAO Fisheries Series 5, 379-487 (1981). 
76. Owen, K. et al. Potential energy gain by whales outside of the Antarctic: prey preferences and consumption rates of migrating humpback whales (Megaptera novaeangliae). Polar Biol 40, 277289 (2017).

77. Innes, S., Lavigne, D. M., Earle, W. M. \& Kovacs, K. M. Estimating Feeding Rates of Marine Mammals from Heart Mass to Body Mass Ratios. Marine Mammal Science 2, 227-229 (1986).

78. Taylor, L. R. Aggregation, Variance and the Mean. Nature 189, 732-735 (1961).

79. Gatesy, J. et al. A phylogenetic blueprint for a modern whale. Mol. Phylogenet 66, 479-506 (2013).

80. Kooyman, G. L., Castellini, M. A. \& Davis, R. W. Physiology of Diving in Marine Mammals. Annu Rev Physiol 43, 343-356 (1981).

81. de Baar, H. J. W. \& De Jong, J. Distributions, sources and sinks of iron in seawater. in The biogeochemistry of iron in seawater (eds. Turner, D. \& Hunter, K.) vol. 7 123-253 (2001).

82. Pollard, R. T. et al. Southern Ocean deep-water carbon export enhanced by natural iron fertilization. Nature 457, 577-580 (2009). 
Figure 1. The two main ways of carbon sequestration in the deep ocean by baleen whales. Directly through the sinking of their carcasses (a) and indirectly through the fertilization of the ocean by nutrients in faeces and the sinking of resulting surplus of phytoplankton (b).

Figure 2: Amount of carbon sequestered annually in the deep Southern Ocean by baleen whales. Via the pathway of whale carcasses (a) and the pathway of phytoplankton fertilization (b) for each whale species and all together at the pre-exploitation level with associated uncertainty. On the top right, the relative contribution of each species. Errors bars represent high and low estimations for carbon sequestration.

753

Figure 3: Dynamics of carbon sequestration generated by the five baleen whale species. Via the two pathways (carcasses and fertilization) between 1890 and 2100 without climate change (a) and with climate change (b). Above the curves the species with the highest contribution to the total sequestration is represented. Vertical bars represent the switch between two major contributing species. Shaded areas represent the high and low estimations for carbon sequestration.

Figure 4: Cumulative carbon sequestration deficit from 1890 to 2100 in the deep Southern Ocean by baleen whales. The total amount of non-sequestered carbon is compared to the pre-exploitation levels of whale populations, without climate change (a) and with climate change (b). Cumulative carbon sequestration deficit for each species without climate change (C) and with climate change (D). Shaded areas represent the high and low estimations for carbon deficit. 


\section{Figures}

767

768 Figure 1

(a) Direct sequestration pathway

(b) Indirect sequestration pathway

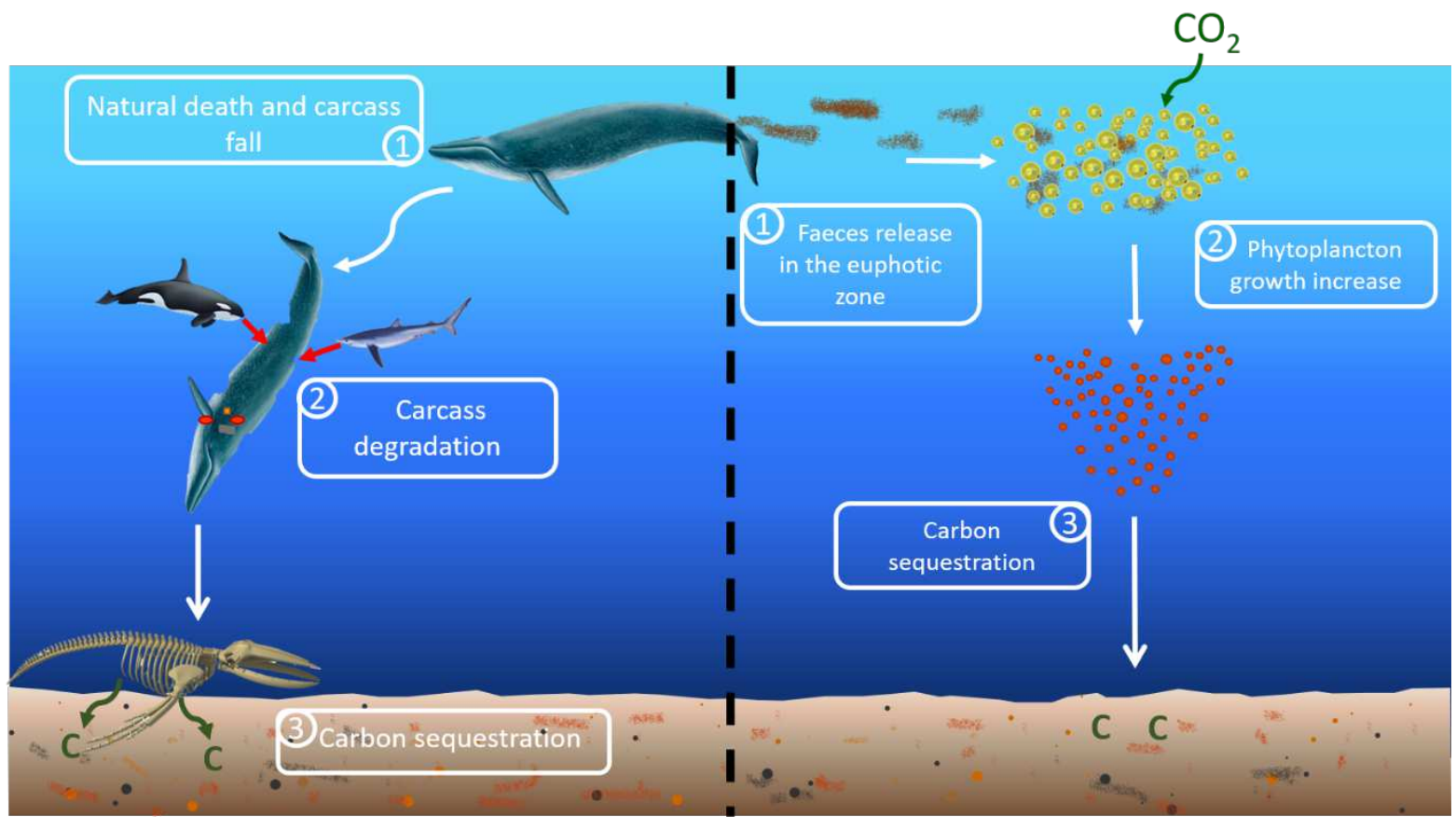

769

Figure 2

(a) Direct sequestration pathway

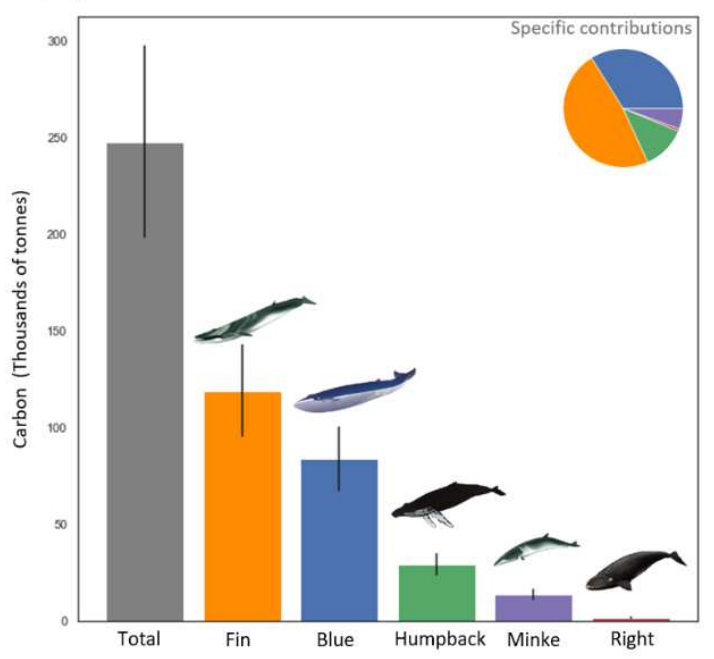

(b) Indirect sequestration pathway

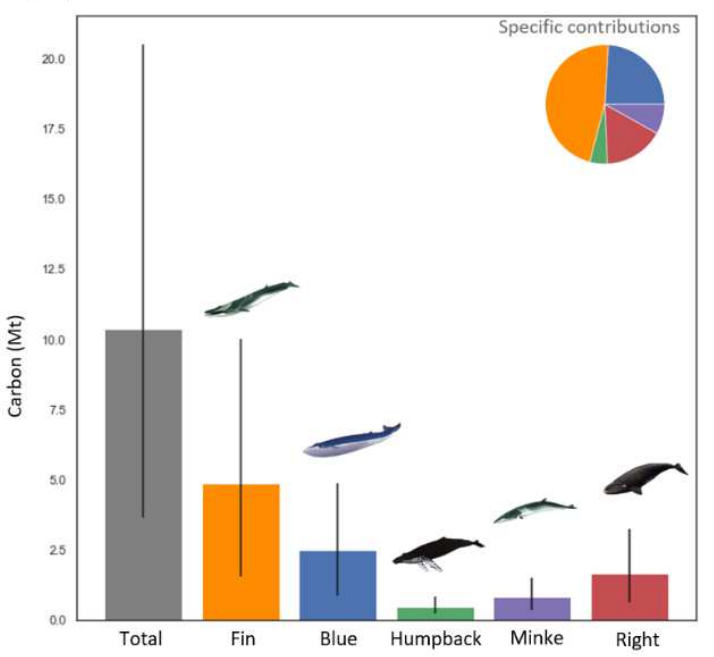


Figure 3
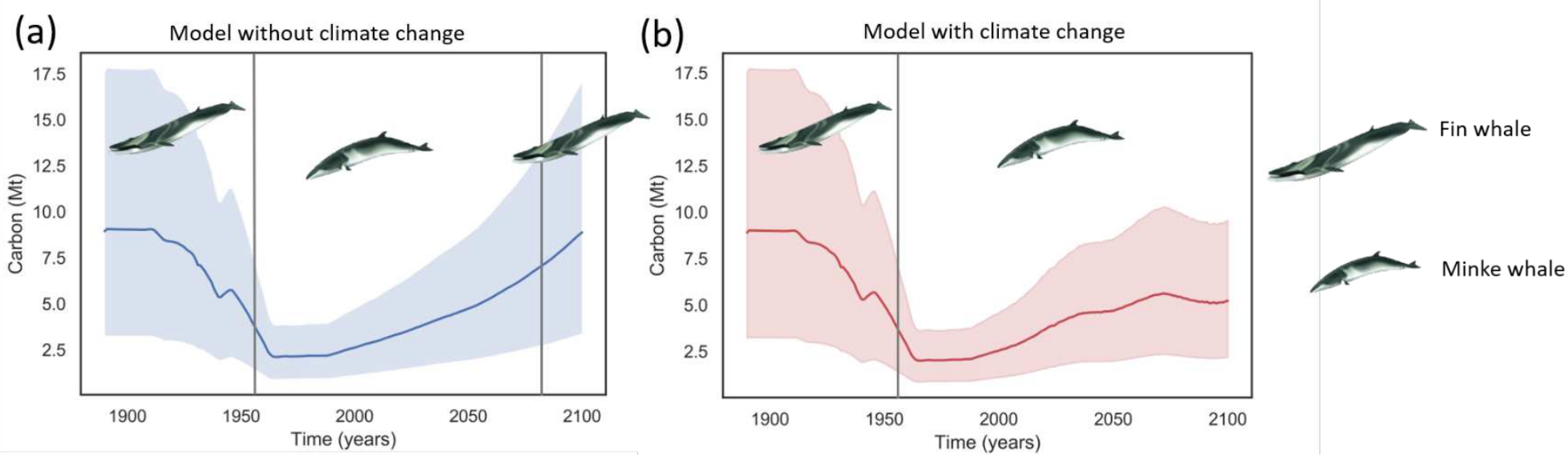

776

777

778

779

Figure 4

780
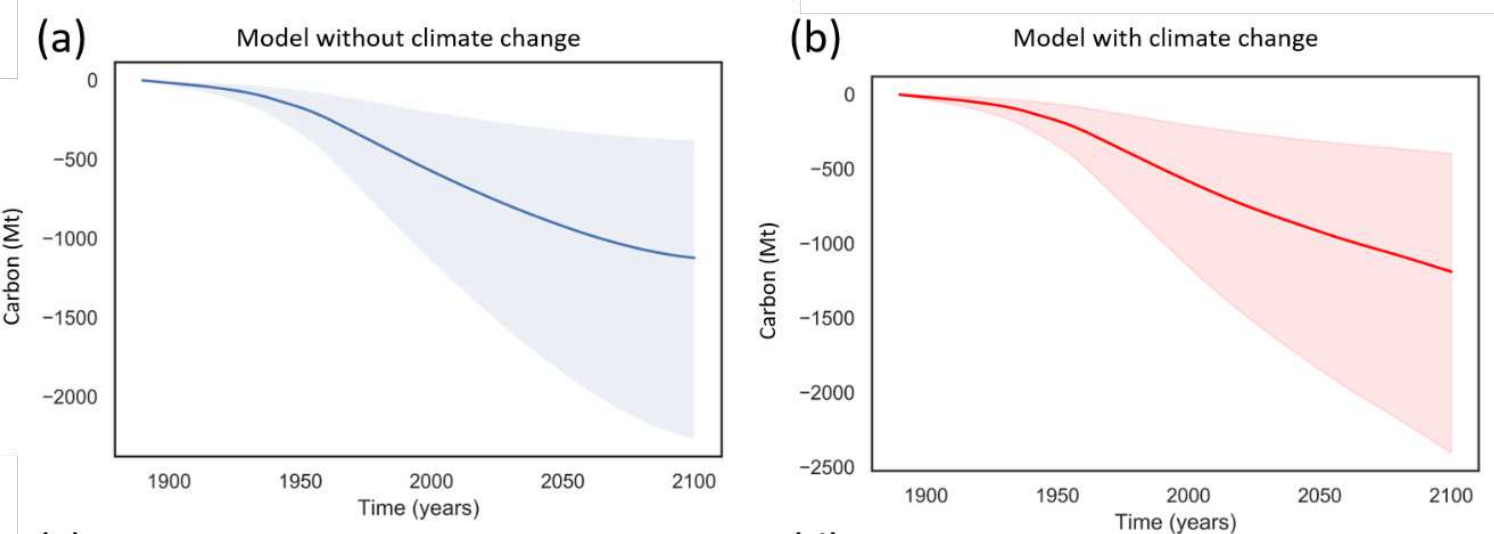

(c)

(d)
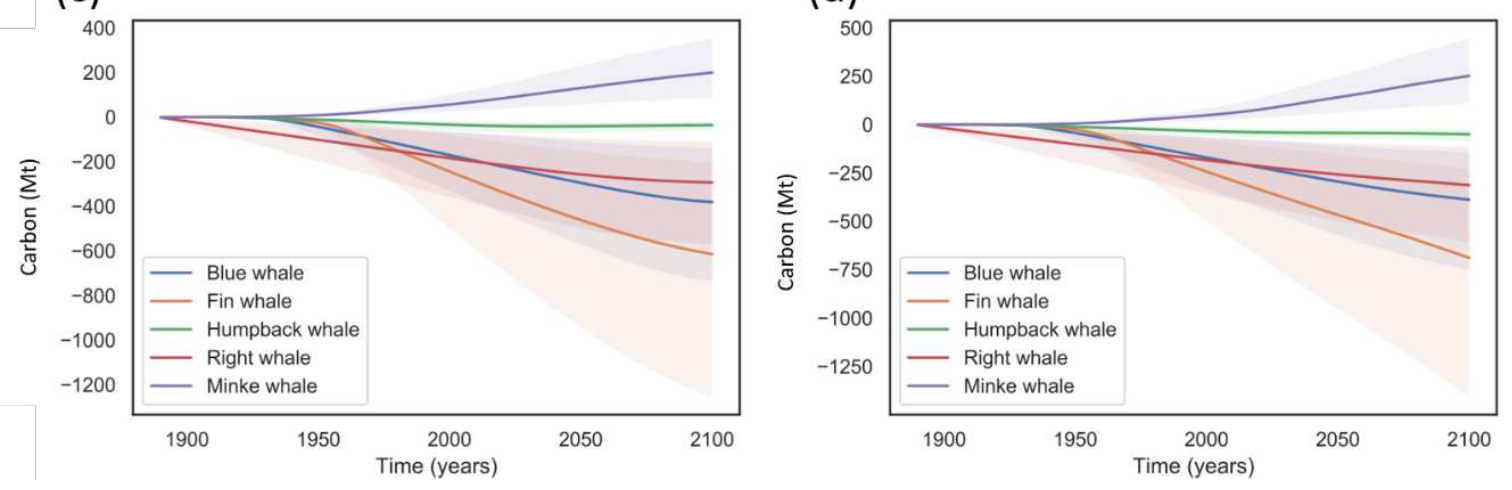

781 


\section{Figures}

(a) Direct sequestration pathway

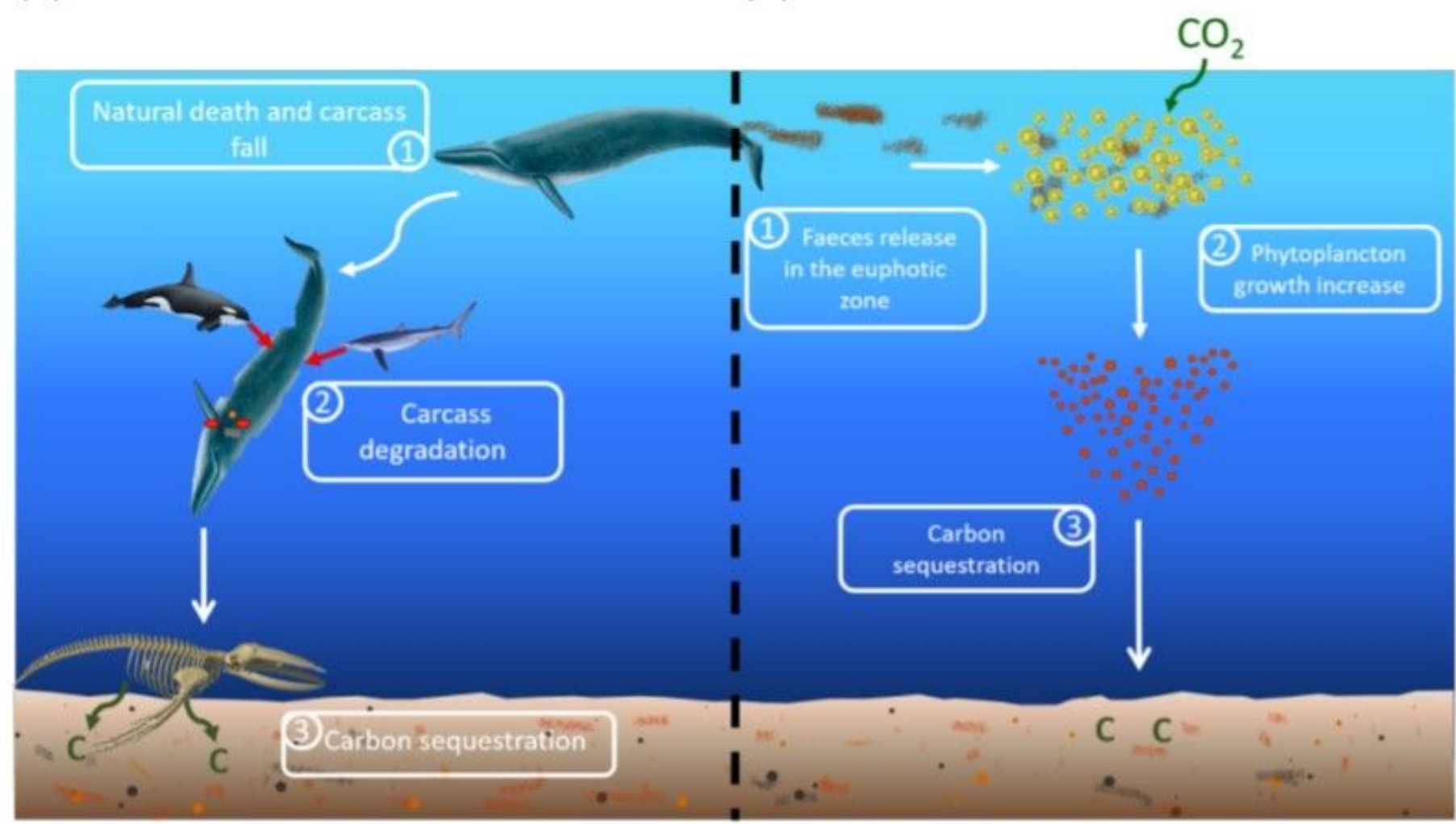

\section{Figure 1}

The two main ways of carbon sequestration in the deep ocean by baleen whales. Directly through the sinking of their carcasses (a) and indirectly through the fertilization of the ocean by nutrients in faeces and the sinking of resulting surplus of phytoplankton (b). 
(a) Direct sequestration pathway

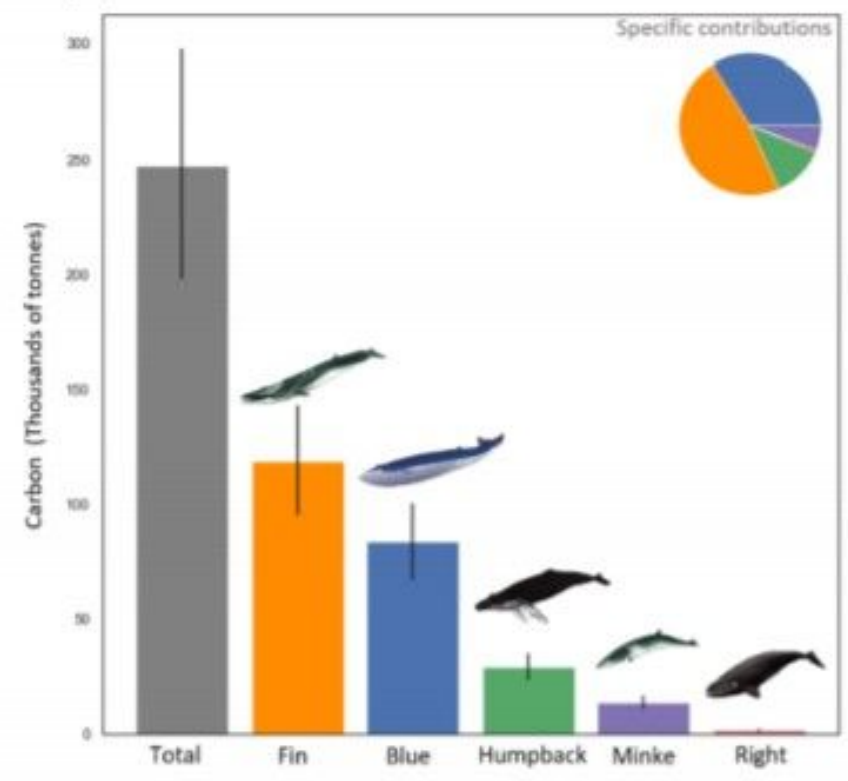

(b) Indirect sequestration pathway

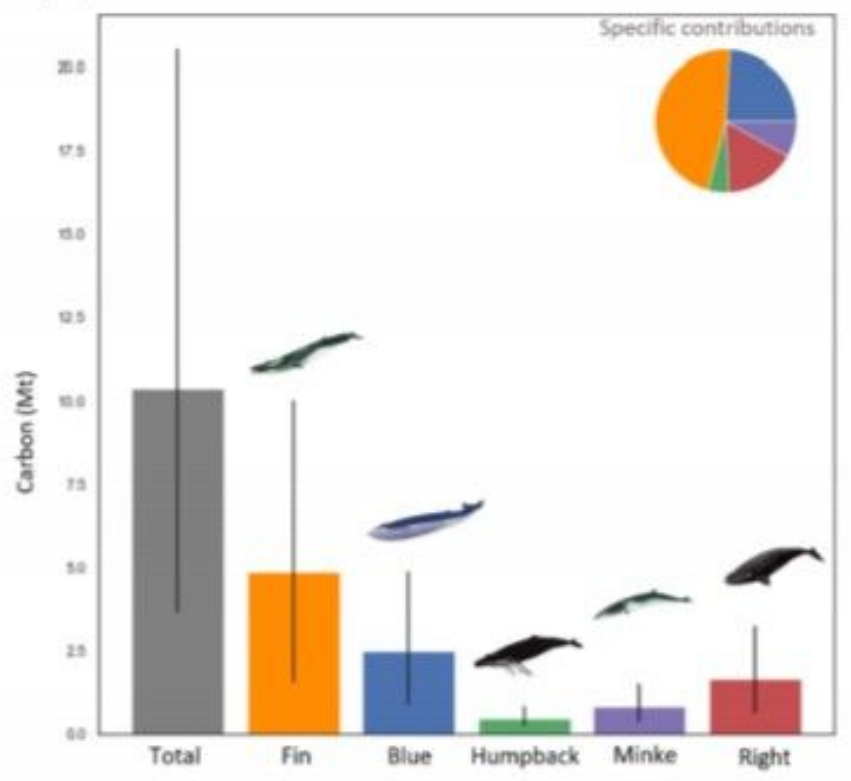

Figure 2

Amount of carbon sequestered annually in the deep Southern Ocean by baleen whales. Via the pathway of whale carcasses (a) and the pathway of phytoplankton fertilization (b) for each whale species and all together at the pre-exploitation level with associated uncertainty. On the top right, the relative contribution of each species. Errors bars represent high and low estimations for carbon sequestration.
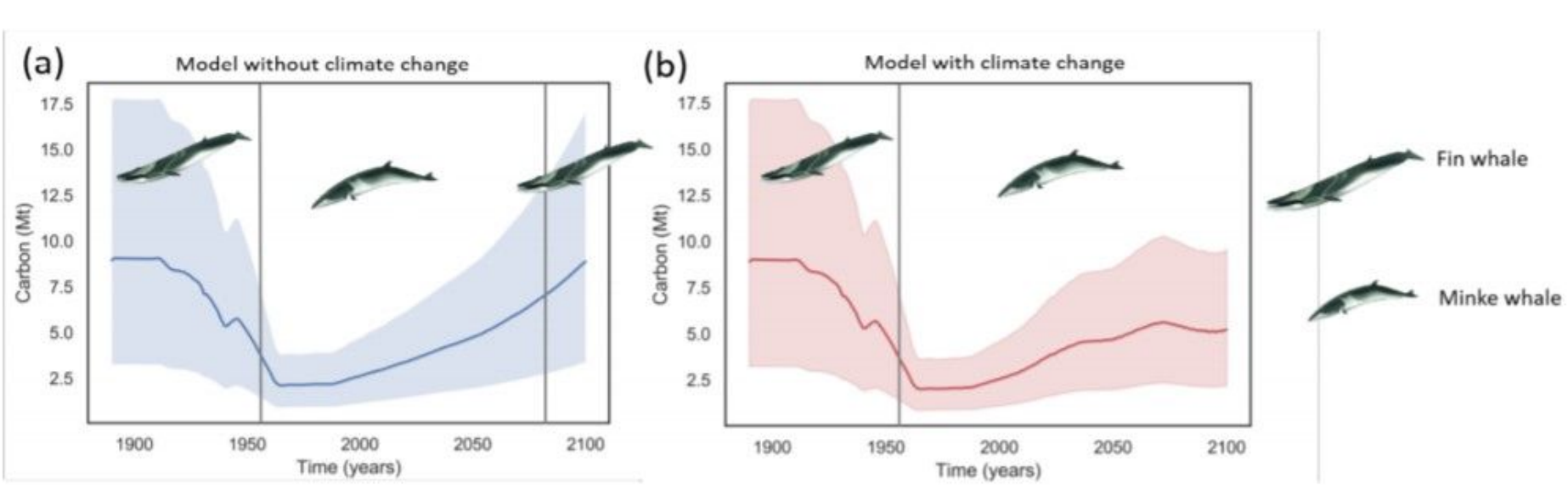

Figure 3

Dynamics of carbon sequestration generated by the five baleen whale species. Via the two pathways (carcasses and fertilization) between 1890 and 2100 without climate change (a) and with climate change (b). Above the curves the species with the highest contribution to the total sequestration is represented. 
Vertical bars represent the switch between two major contributing species. Shaded areas represent the high and low estimations for carbon sequestration.
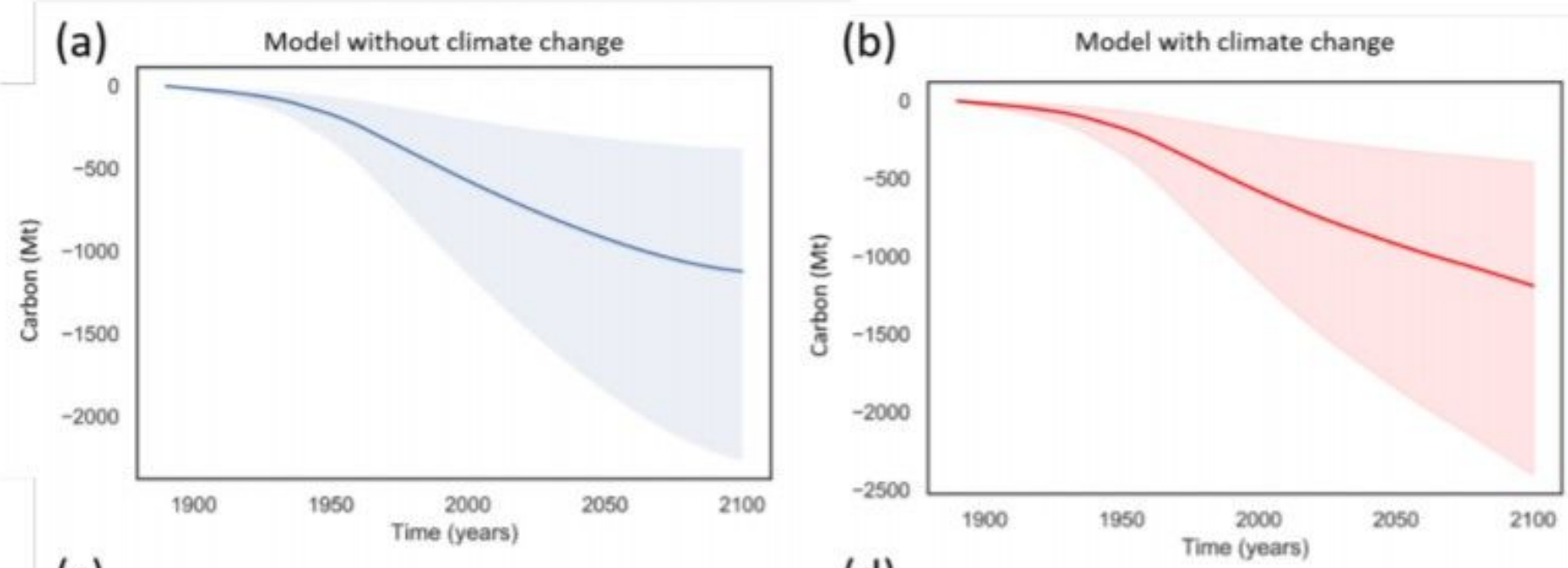

(c)

(d)
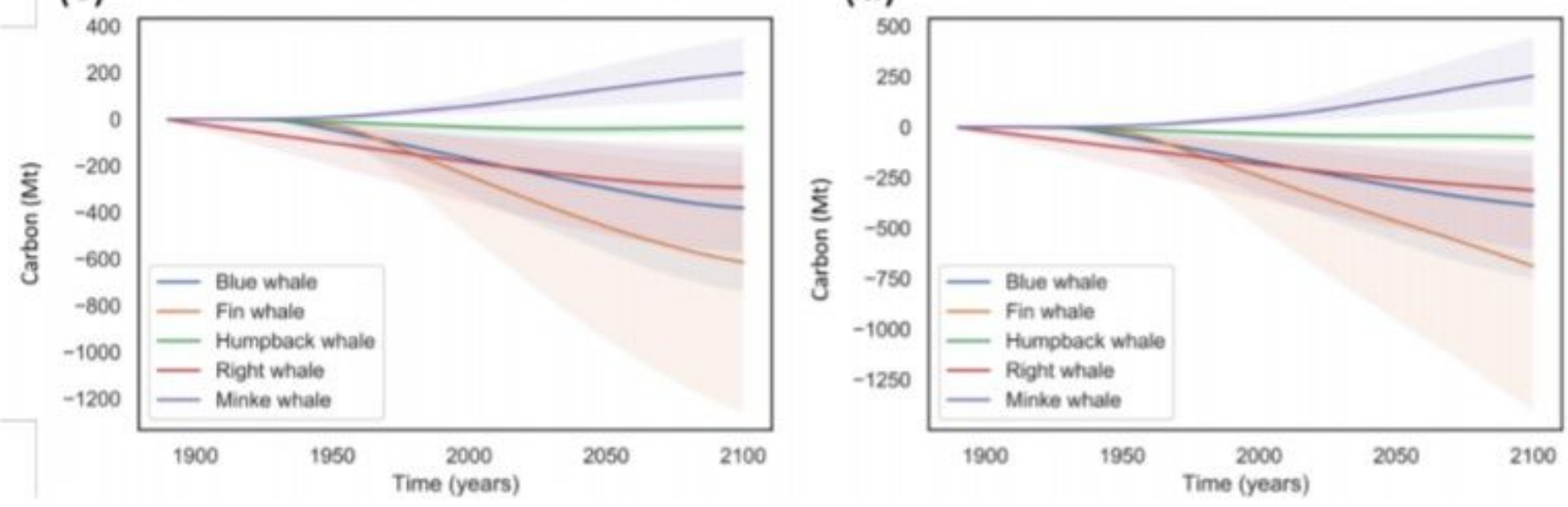

\section{Figure 4}

Cumulative carbon sequestration deficit from 1890 to 2100 in the deep Southern Ocean by baleen whales. The total amount of non-sequestered carbon is compared to the pre-exploitation levels of whale populations, without climate change (a) and with climate change (b). Cumulative carbon sequestration deficit for each species without climate change (C) and with climate change (D). Shaded areas represent the high and low estimations for carbon deficit.

\section{Supplementary Files}

This is a list of supplementary files associated with this preprint. Click to download.

- Durfortetal.NatComSI.pdf

- NatComSIBlind.pdf 